\title{
Relative Abundance and Local Uses of Wild Trees Species in Ukohol Community, Guma Local Government Area of Benue State, Nigeria
}

\author{
${ }^{1}$ Adagba, M. N., Shomkegh, S.A ${ }^{2}$ and Ikyaagba, E. T ${ }^{2}$ \\ ${ }^{l}$ Department of Forest Production and Products, College of Forestry and Fisheries, University of Agriculture, \\ Makurdi, Nigeria \\ ${ }^{2}$ Department of Social and Environmental Forestry, College of Forestry and Fisheries, University of \\ Agriculture, Makurdi, Nigeria
}

\begin{abstract}
The study sought to estimate the relative abundance and uses of wild tree species in Ukohol community. Six transects were laid at a range of $500 \mathrm{~m}$ within a $5 \mathrm{~km}$ baseline through fallowlands in the community. On each transect, 4 plots of $50 \mathrm{~m} \times 50 \mathrm{~m}$ were marked and the total number of each species in the plots was counted and recorded. A semi-structured questionnaire was also administered to 40 respondents in four out of six villages in the study area to obtain information on uses of the tree species. A total of 38 plant species from 17 families were recorded. The Dbh classes in the study area ranged between less than $20 \mathrm{~cm}$ to below $80 \mathrm{~cm}$. The tree species in the community were used for food, medicines, crafts, local construction materials, fuelwood and charcoal making. Plants with multiple uses such as Prosopis africana with a CI of 5.5, Vitellaria paradoxa (4.2) and Burkea africana (3.9) were rated high by respondents. Tree species in the area were less diverse but useful to the people. It is recommended that planting of these species be prioritized to ensure their sustainability in the community.
\end{abstract}

Keywords: Wild trees, relative abundance, local knowledge, importance value index, Ukohol community

\section{Introduction}

Traditional ecological knowledge refers to people's knowledge, practices and beliefs about the relationships between organisms and their biophysical environment (Berkes, 2008). Traditional knowledge is a cumulative body of knowledge, know-how, practices and representations maintained and developed by people with extended histories of interaction with the natural environment (Lepage et al., 2007). The association between knowledge of plants and the uses of these plants depends on the ecosystem from which the plants were derived; people used plants they knew about from the forest (Ladio and Lozada, 2004). Accumulated knowledge and traditional practices of indigenous communities are a powerful resource that can greatly facilitate the task of identifying useful new varieties of domestic plants or animals, isolating novel biological components, or developing innovative technologies and techniques (Munn, 2002). The existence of plants species in any habitat is crucial to man and other components of the ecosystem as all plants are valuable for one purpose or the other (Olapade and Bakare, 1992) but anthropogenic activities can influence plants by modifying their environment, especially their resource base -the soil (Buba, 2015). In addition, the distribution, abundance and structure of plant species are shaped by biotic and abiotic factors such as rainfall, temperature, topography, soil, luminosity and human activities (Wala et al., 2012, Mendoza-González et al., 2012). Fraterrigo et al., (2006) and Latzal, (2008) affirmed that the performance and success of plants depends partly on the soil composition and characteristics, with frequent anthropogenic disturbances playing a major role in shaping and determining plant community composition and distribution. According to Buba (2015), human disturbances arising from different types of land use can directly affect plants by damaging the plant's conducting tissues and leaves, which may result in growth retardation or death of the plant. Tillage also affects plant community composition and diversity and this reflects in the relaxation of competition due to the elimination of dominant species, which takes time to reestablish (Daniellie et al., 2008, Dinnage, 2009). Another attribute of human disturbances is heavy grazing which alters species abundance and their functional composition in an area (Kukshal et al., 2009, Hanke et al., 2014). Tree harvesting arising mainly from unsustainable farming practices, timber, craft making, charcoal production, fuelwood and grazing/trampling have deepened in Ukohol community. Preferred tree species are frequently sought for these purposes even beyond the community but baseline information on their uses and relative abundance in the area is lacking. This study therefore sought to estimate the relative abundance and document the uses categories of tree species harvested in the area in order to provide information on the status and uses of wild tree plants in the area. 


\subsection{Study area}

\section{Materials And Methods}

The Ukohol community is located in Guma Local Government Area (LGA), Benue North in NorthCentral Nigeria. The area is characterized by two distinct seasons, the wet and dry season respectively. The wet season commences from April -November while the dry season begins from November to March. The major tribe in the area is the Tiv people, who are predominantly farmers. The vegetation is the open savanna woodland characterized by scattered trees within vast grasslands.

\subsection{Data Collection}

Tree species composition, distribution and diameter at breast height was estimated through a field survey to obtain the status of each tree species utilized in the community while semi-structured interviews with heads of selected households in the community provided information on the use categories of tree species in the study area

\subsubsection{Tree composition, distribution and estimation of diameter at breast height}

Six (6) transects were laid at a range of $500 \mathrm{~m}$ within a $5 \mathrm{~km}$ base line through the fallowlands in the community between February and March, 2016. On each transect, 4 plots of 50m x 50m each were marked and the total number of each tree species in each of the plots was counted and recorded (Brerly et al., 2004). The Dbh of each species was measured and Dbh classes assigned to each of the trees encountered according to Turyahabwe and Tweheyo (2010). Trees recorded were identified through their local names with the aid of Agishi (2010) and botanical information obtained from Arbonnier (2004), Keay (1989) and support from virtual plant identification platforms especially Angiosperm Phylogeny Group (APG III).

\subsubsection{Species Diversity}

Species diversity refers to the number of species and their relative abundance in a defined area (Sanderson $e t$ al., 2004). This was determined using relative frequency; relative density and Importance Value Index, estimated according to Maingi and Marsh, 2006 and Adams et al., 2007).

\section{Relative Frequency (RF)}

This gave an indication of the degree of dispersion of individual tree species in relation to all other tree species present in the area, calculated as follows;

Relative Density $(\mathrm{RF})=$ Frequency of individual species $\mathrm{x} 100$

Total frequency of all species

Relative Density (RD)

The relative density provided information on the distribution of tree plants in the area and is expressed as;

Relative Density $(\mathrm{RD})=$ Number of individual species $\times 100$

Total number of species

\subsubsection{The Importance Value Index (IVI)}

The Importance Value Index (IVI) of each tree species was estimated by obtaining the sum of relative frequency and relative density of the tree species. It gave an indication of which tree species was dominant over the other. The Importance Value Index (IVI) = RF + RD.

\subsubsection{Semi-Structured Interviews}

A semi-structured questionnaire was administered to 40 respondents in four out of six villages in Ukohol community to obtain information on use categories of tree species in the area. The list of plants and their uses was compiled and documented. The number of citations (CI) for each plant was estimated as provided below;

The number of citations $(\mathrm{CI})=$ Total number of citations of an individual plant

Total number of respondents

\section{Results and Discussion}

\subsection{Floristic Composition and Distribution of tree species in Ukohol community.}

A total of 38 plant species from 17 families were recorded (Table 1) with combretaceae having the highest number of species (6), followed by Rubiaceae and Caesalpinioidaeae with 5 species each (Fig. 1). Nine (9) families had 1 species each, mainly from species with multiple uses or high rating for craft making, timber and charcoal production. Species such as Daniellia oliveri, Parkia biglobosa, Ficus sur and Mitrygyna inermis were more diverse with relative frequency of 5.95 each and among the most abundant species with a relative density of $8.24,8.79,8.24$ and 6.59 respectfully. Parkia biglobosa had the highest IVI of 14.74 due to its 
multiple uses such as fish poisoning, condiment/food additive, local construction, medicine and shelter (Shomkegh et al., 2016). This was followed by Sarcpocephalus latifolia with an IVI of 13.55, Khaya senegalensis (10.26), Combretum nigricans (9.16) and Bridelia ferruginea (7.97). Twelve species had the least IVI of 1.74 among preferred species in the community due mainly to their lower numerical strength as all the species had very low relative densities $(0.55)$ compared with the other tree species in the community.

Table 1: Tree species encountered and the Importance Value Index in Ukohol community

\begin{tabular}{|c|c|c|c|c|c|c|}
\hline S/No & Botanical name & Family & $\begin{array}{c}\text { Local name } \\
\text { (Tiv) }\end{array}$ & $\begin{array}{c}\text { Relative } \\
\text { frequency } \\
\text { (RF) }\end{array}$ & $\begin{array}{c}\text { Relative } \\
\text { Density } \\
\text { (RD) } \\
\end{array}$ & $\begin{array}{l}\text { Importance } \\
\text { Value Index } \\
\text { (IVI) }\end{array}$ \\
\hline 1 & Acacia nilotica & Mimosoideae & Saa anula & 1.190476 & 0.549451 & 1.739927 \\
\hline 2 & Afzelia africana & Caesalpinoideae & Yiase & 1.190476 & 0.549451 & 1.739927 \\
\hline 3 & Ancardium occidentale & Anacardiaceae & Ishase & 2.380952 & 2.197802 & 4.578755 \\
\hline 4 & Anogeissus leiocarpa & Combretaceae & Maaki & 1.190476 & 0.549451 & 1.739927 \\
\hline 5 & Anthocleista djelonensis & Loganiaceae & Kookoso & 1.190476 & 0.549451 & 1.739927 \\
\hline 6 & Borassus aethiopum & Boraginaceae & Akuugh & 1.190476 & 1.098901 & 2.289377 \\
\hline 7 & Bombax costatum & Bombacaceae & Genger & 1.190476 & 0.549451 & 1.739927 \\
\hline 8 & Bridelia ferrugiena & Euphorbiaceae & Ikpine & 3.571429 & 4.395604 & 7.967033 \\
\hline 9 & Combretum molle & Combretaceae & Azulugh & 2.380952 & 1.648352 & 4.029304 \\
\hline 10 & Combretum nigricans & Combretaceae & Alo & 4.761905 & 4.395604 & 9.157509 \\
\hline 11 & Crossopteryx febrifuga & Rubiaceae & Iikwar & 2.380952 & 2.747253 & 5.128205 \\
\hline 12 & Daniella oliveri & Caesalpinoideae & Chiha & 5.952381 & 8.241758 & 14.19414 \\
\hline 13 & Detarium microcarpum & Caesalpinoideae & Lienegh & 2.380952 & 3.296703 & 5.677656 \\
\hline 14 & Entada africana & Mimosoideae & Liemen & 2.380952 & 1.648352 & 4.029304 \\
\hline 15 & Ficus sur & Moraceae & Tur & 5.952381 & 8.241758 & 14.19414 \\
\hline 16 & Ficus sycomorus & Moraceae & Hirkar & 3.571429 & 2.747253 & 6.318681 \\
\hline 17 & Gardenia aqualla & Rubiaceae & Ishondugh & 1.190476 & 0.549451 & 1.739927 \\
\hline 18 & Gardenia erubescens & Rubiaceae & Ibohogh & 1.190476 & 0.549451 & 1.739927 \\
\hline 19 & Gmelina arborea & Verbenaceae & Malina & 2.380952 & 2.197802 & 4.578755 \\
\hline 20 & Hymenocardia acida & Hymenocardiaceae & Iikwar tor & 1.190476 & 0.549451 & 1.739927 \\
\hline 21 & Khaya senegalensis & Meliaceae & Наa & 4.761905 & 5.494505 & 10.25641 \\
\hline 22 & Lannea schimperiana & Anacardiaceae & Ipungwa & 3.571429 & 2.747253 & 6.318681 \\
\hline 23 & Mitrygyna inermis & Rubiaceae & Sohonor & 5.952381 & 6.593407 & 12.54579 \\
\hline 24 & Morinda lucida & Moraceae & Ikpine-puupuu & 3.571429 & 2.197802 & 5.769231 \\
\hline 25 & Parkia biglobosa & Mimosoideae & Nune & 5.952381 & 8.791209 & 14.74359 \\
\hline 26 & Parinari curatellifolia & Chrysobalanaceae & Ibua-kyuna & 1.190476 & 1.098901 & 2.289377 \\
\hline 27 & Pericopsis laxiflora & Caesalpinoideae & Giragba & 1.190476 & 0.549451 & 1.739927 \\
\hline 28 & Piliostigma thonningii & Caesalpinoideae & Nyihar & 1.190476 & 1.098901 & 2.289377 \\
\hline 29 & Prosopis africana & Mimosoideae & Gbaaye & 3.571429 & 2.197802 & 5.769231 \\
\hline 30 & Pterocarpus erinaceus & Papilionoideae & Ngaji & 1.190476 & 1.098901 & 2.289377 \\
\hline 31 & Sarcocephalus latifolia & Rubiaceae & Ikura-ukase & 4.761905 & 8.791209 & 13.55311 \\
\hline 32 & Strychnos spinosa & Loganiaceae & Maku & 2.380952 & 2.197802 & 4.578755 \\
\hline 33 & Syzygium guinenses & Myrtaceae & Daanyam & 1.190476 & 0.549451 & 1.739927 \\
\hline 34 & Terminalia avicenniodes & Combretaceae & Kwegh & 3.571429 & 3.296703 & 6.868132 \\
\hline 35 & Terminalia schimperiana & Combretaceae & Ukwegh & 1.190476 & 0.549451 & 1.739927 \\
\hline 36 & Terminalia catarpa & Combretaceae & Hii-pine & 1.190476 & 0.549451 & 1.739927 \\
\hline 37 & Vitallaria paradoxa & Sapotaceae & Chamegh & 2.380952 & 2.747253 & 5.128205 \\
\hline 38 & Vitex donniana & Verbenaceae & Hulugh & 2.380952 & 2.197802 & 4.578755 \\
\hline
\end{tabular}

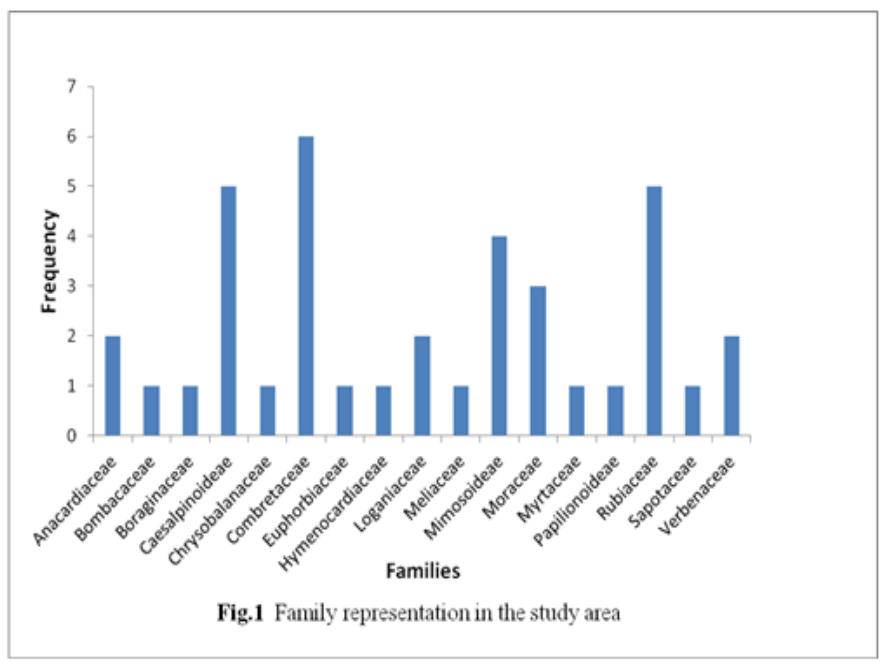




\subsection{Diameter at Breast Height (Dbh) classes of tree species in the study area}

The Dbh classes in the study area ranged between less than $20 \mathrm{~cm}$ to below $80 \mathrm{~cm}$. This gives an indication of absence of large trees species in the area. Dbh class $41-60 \mathrm{~cm}$ had the highest number of tree species (25) but with only 40 individual plants, lower than Dbh range $41-60 \mathrm{~cm}$ which had the highest number of individual plants (76) from 25 species as shown in Fig.2. Dbh of less than $20 \mathrm{~cm}$ had 15 species with 26 individual plants. The oldest classes of trees were fewer, having 11 species with a total of 18 individuals compared with all other classes. This could be linked to the high rate of deforestation arising from destructive harvesting of merchantable trees for craft making, timber, charcoal production and fuelwood. Using Turkey's pairwise comparison, DBH class $21-40 \mathrm{~cm}$ was found to be significantly different with Dbh class less than $20 \mathrm{~cm}$; similarly, Dbh class $61-80 \mathrm{~cm}$ and $81 \mathrm{~cm}$ beyond were significantly different from other classes(Table 2). This implies that the observed differences in most of the Dbh classes were not significantly different as only the few highlighted above were different. Seventy-five percent $(75 \%)$ of trees species in the area were moderately harvested while $25 \%$ believed to be most preferred species were heavily harvested (Table 3). All the respondents agreed that there has been a decline in tree population in the area in the last 10 years. The major reasons for the decline were unsustainable farming practices (62.5\%) and craft making (20\%) which was observed to be a lucrative business for energetic young men who were seen operating the venture in several mini camps along the Makurdi-Lafia expressway. Timber harvesting accounted for $10 \%$ due lack of merchantable timber species in the area. Charcoal production was said to be practiced in the past but was no longer operational due to scarcity of Prosopis africana, the most preferred species because of its high heating value. Mortar carvers who noted that they go outside the Local Government Area to purchase the tree and transport it back for their business. Majority of respondents $(87.5 \%)$ in the area admitted that they do not plant these trees species, which poses a bleak future for tree utilization in the area.

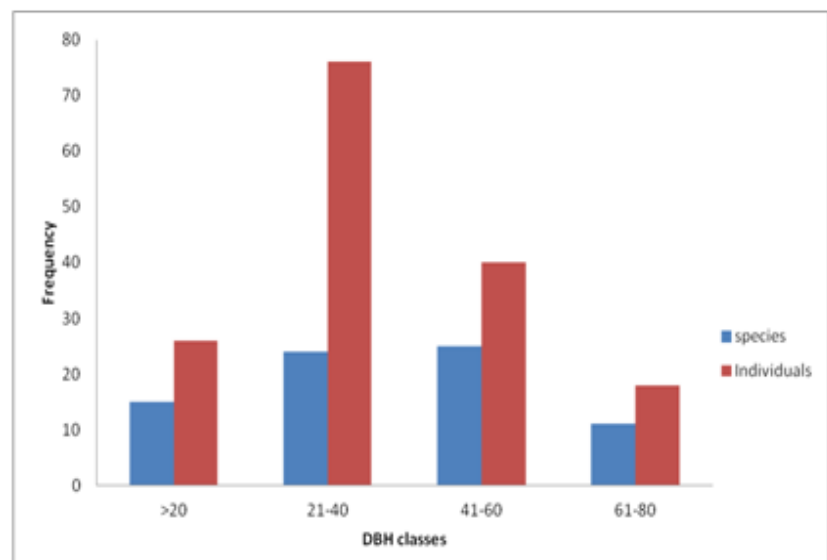

Fig. 2 DBH classes distribution in the study area

Table 2: Tukey's pairwise comparison of species distribution in the study area

\begin{tabular}{|l|l|l|l|l|l|}
\hline DBH classes $(\mathrm{cm})$ & $<20$ & $21-40$ & $41-60$ & $61-80$ & $81 \&$ above \\
\hline$<20$ & & $0.002172^{* *}$ & $0.841^{\mathrm{ns}}$ & $0.9767^{\mathrm{ns}}$ & $0.9276^{\mathrm{ns}}$ \\
\hline $21-40$ & & & $0.06141^{\mathrm{ns}}$ & $0.2009^{* *}$ & $8.333 \mathrm{E}-05^{* *}$ \\
\hline $41-60$ & & & & $0.4842^{\mathrm{ns}}$ & $0.3496^{\text {ns }}$ \\
\hline $61-80$ & & & & & $0.9995^{\mathrm{ns}}$ \\
\hline $80 \&$ above & & & & & \\
\hline
\end{tabular}

Note $* *$ significant at $5 \% \mathrm{~ns}=$ not significant at $5 \%$

Table 3: Reasons for tree species decline in the study area

\begin{tabular}{|l|l|l|l|}
\hline \hline Variable & Parameters & Frequency & $\begin{array}{l}\text { Percentage } \\
\text { frequency }(\%)\end{array}$ \\
\hline Harvesting intensity of trees & Heavily & 10 & 25 \\
\hline & Moderate & 30 & 75 \\
\hline & Light & 0 & 0 \\
\hline & Do not know & 0 & 0 \\
\hline $\begin{array}{l}\text { Are there tree species which were available } \\
\text { in last 10 years rare or absent now? }\end{array}$ & Yes & 40 & 100 \\
\hline & No & 0 & 0 \\
\hline Reasons for tree species decline & Farming & 25 & 62.5 \\
\hline & Charcoal production & 0 & 0 \\
\hline & Fire & 0 & 0 \\
\hline & Fuelwood collection & 3 & 7.5 \\
\hline
\end{tabular}


Relative Abundance and Local Uses of Wild Trees Species in Ukohol Community, Guma Local

\begin{tabular}{|l|l|l|l|}
\hline & Timber & 4 & 10 \\
\hline & Craft making & 8 & 20 \\
\hline $\begin{array}{l}\text { Do you plant some of the tree species in your } \\
\text { area? }\end{array}$ & Yes & 5 & 12.5 \\
\hline & No & 35 & 87.5 \\
\hline
\end{tabular}

\subsection{Local uses of tree species in the study area}

\subsubsection{Demographic information of study respondents}

Forty (40) heads of households in the four villages made up of $65 \%$ men and 35\% women mainly within the ages of 21-40 years were interviewed in the study area (Table 4). Elderly people were between the ages of 41-60 years constituting 10\% of the surveyed population. The respondents were all married with their primary vocation as farming. On their educational status, most of them had primary school education $(47.5 \%)$, while secondary and tertiary education had 5\% each. Tree species in the area were used as food, medicines, crafts, local construction materials, fuelwood and charcoal making (Table 5). Tree plants with multiple uses such as Prosopis africana, Vitellaria paradoxa and Burkea africana had a CI of 5.5, 4.2 and 3.9 respectively and were rated high by respondents. Fourteen (14) tree species were the least cited with a CI of less than 2. Plants parts such as leaves, seeds, fruits, root and trunk were used for each of the use categories (Fig. 3). Plant parts utilized for food were the leaves, seed and fruits depending on the tree species. Plants with medicinal values utilized roots, seeds, leaves and trunk (bark) of different tree species depending on the ailment treated. Craft making, local construction, fuelwood and charcoal production used mainly the trunk of tree species in the area.

Table 4: Demographic data of study respondents

\begin{tabular}{|l|l|l|l|}
\hline Variable & Frequency & Percentage frequency (\%) \\
\hline \multirow{3}{*}{ Sex } & Male & 26 & 65 \\
\cline { 2 - 4 } & Female & 14 & 35 \\
\hline \multirow{5}{*}{ Age } & $<20$ & 0 & 0 \\
\cline { 2 - 4 } & $21-40$ & 36 & 90 \\
\cline { 2 - 4 } & $41-60$ & 4 & 10 \\
\cline { 2 - 4 } & $61-80$ & 0 & 0 \\
\cline { 2 - 4 } & 81 above & 0 & 0 \\
\hline Occupation & Farming & 40 & 100 \\
\hline Marital status & Married & 40 & 100 \\
\hline Educational status & Non formal & 17 & 42 \\
\cline { 2 - 4 } & Primary & 19 & 47.5 \\
\cline { 2 - 4 } & Secondary & 2 & 5 \\
\cline { 2 - 4 } & Tertiary & 2 & 5 \\
\hline & Total & $\mathbf{4 0}$ & $\mathbf{1 0 0}$ \\
\hline
\end{tabular}

Table 5: Uses of tree species in Ukohol community

\begin{tabular}{|c|c|c|c|c|c|c|c|c|c|c|}
\hline$S / n$ & Scientific name & Family & Local name & Food & Medicine & Crafts & $\begin{array}{l}\text { Local } \\
\text { Construction }\end{array}$ & $\begin{array}{l}\text { fuel } \\
\text { wood }\end{array}$ & charcoal & CI \\
\hline 1 & Prosopis africana & Mimosoideae & Gbaaye & 40 & 21 & 40 & 40 & 40 & 40 & 5.525 \\
\hline 2 & Parkia biglobosa & Mimosoideae & Nune & 40 & 21 & 0 & 0 & 32 & 0 & 2.325 \\
\hline 3 & Ficus sur & Moraceae & Tur & 40 & 31 & 0 & 0 & 20 & 0 & 2.275 \\
\hline 4 & Vitex doniana & Verbenaceae & Hulugh & 40 & 35 & 0 & 0 & 0 & 0 & 1.875 \\
\hline 5 & Saba florida & Apocynaceae & Ipungwa & 40 & 11 & 0 & 25 & 0 & 0 & 1.900 \\
\hline 6 & Mangifera indica & Anacardiaceae & Mango & 40 & 4 & 0 & 0 & 21 & 0 & 1.625 \\
\hline 7 & Burkia africana & Caesalpinoideae & Gbagbongom & 0 & 40 & 21 & 31 & 38 & 27 & 3.925 \\
\hline 8 & Annona sengalensis & Annonaceae & Ahur & 13 & 40 & 0 & 0 & 1 & 0 & 1.350 \\
\hline 9 & Piliostigma thonningii & Caesalpinoideae & Nyihar & 0 & 40 & 0 & 0 & 31 & 0 & 1.775 \\
\hline 10 & Maytenus sengalensis & Celatraceae & Alom & 0 & 40 & 0 & 0 & 20 & 0 & 1.500 \\
\hline 11 & Grewia mollis & Tiliaceae & Hwerbar & 0 & 40 & 0 & 0 & 0 & 0 & 1.000 \\
\hline 12 & Gardenia aqualla & Rubiacea & Shondugh & 0 & 40 & 0 & 0 & 0 & 0 & 1.000 \\
\hline 13 & Daniellia oliveri & Caesalpinoideae & Chiha & 0 & 40 & 0 & 40 & 14 & 0 & 2.350 \\
\hline 14 & Pterocarpus erinaceus & Papilionoideae & Ngaji & 0 & 40 & 40 & 40 & 23 & 12 & 3.875 \\
\hline 15 & Detarium macrocarpum & Caesalpinoideae & Agashi & 2 & 40 & 40 & 0 & 28 & 17 & 3.175 \\
\hline 16 & Afzelia africana & Caesalpinoideae & Yiase & 0 & 40 & 40 & 40 & 32 & 0 & 3.800 \\
\hline 17 & Vitellaria paradoxa & Sapotacaea & Chamegh & 35 & 40 & 40 & 16 & 26 & 11 & 4.200 \\
\hline 18 & Pseudocedra kotschyi & Euporbiaceae & Kpamegh & 0 & 0 & 40 & 0 & 0 & 0 & 1.000 \\
\hline 19 & Khaya sengalensis & Meliaceae & Haa & 0 & 31 & 21 & 40 & 30 & 0 & 3.050 \\
\hline 20 & Anogeisus leiocarpa & Combretaceae & Maaki & 0 & 21 & 7 & 40 & 29 & 26 & 3.075 \\
\hline 21 & Mitragyna inermis & Rubiacea & Sohonor & 0 & 40 & 0 & 0 & 0 & 0 & 1.000 \\
\hline 22 & Crossopteryx febrifuga & Rubiaceae & Irkwar & 0 & 40 & 0 & 0 & 31 & 0 & 1.775 \\
\hline 23 & Sarcocephalus latifolia & Rubiaceae & Ikyura & 0 & 40 & 0 & 0 & 13 & 0 & 1.325 \\
\hline 24 & Allophyllus africanus & Sapindaceae & Apaapa & 0 & 31 & 0 & 0 & 21 & 0 & 1.300 \\
\hline 25 & Azadirachta indica & Meliacea & Dogonyaro & 0 & 40 & 0 & 21 & 0 & 0 & 1.525 \\
\hline
\end{tabular}




\begin{tabular}{|l|l|l|l|l|l|l|l|l|l|}
\hline 26 & Strychnos spinosa & Loganiaceae & Amaku & 37 & 40 & 0 & 0 & 18 & 0 \\
\hline
\end{tabular}

$\mathrm{CI}=$ Number of citations of a particular plant

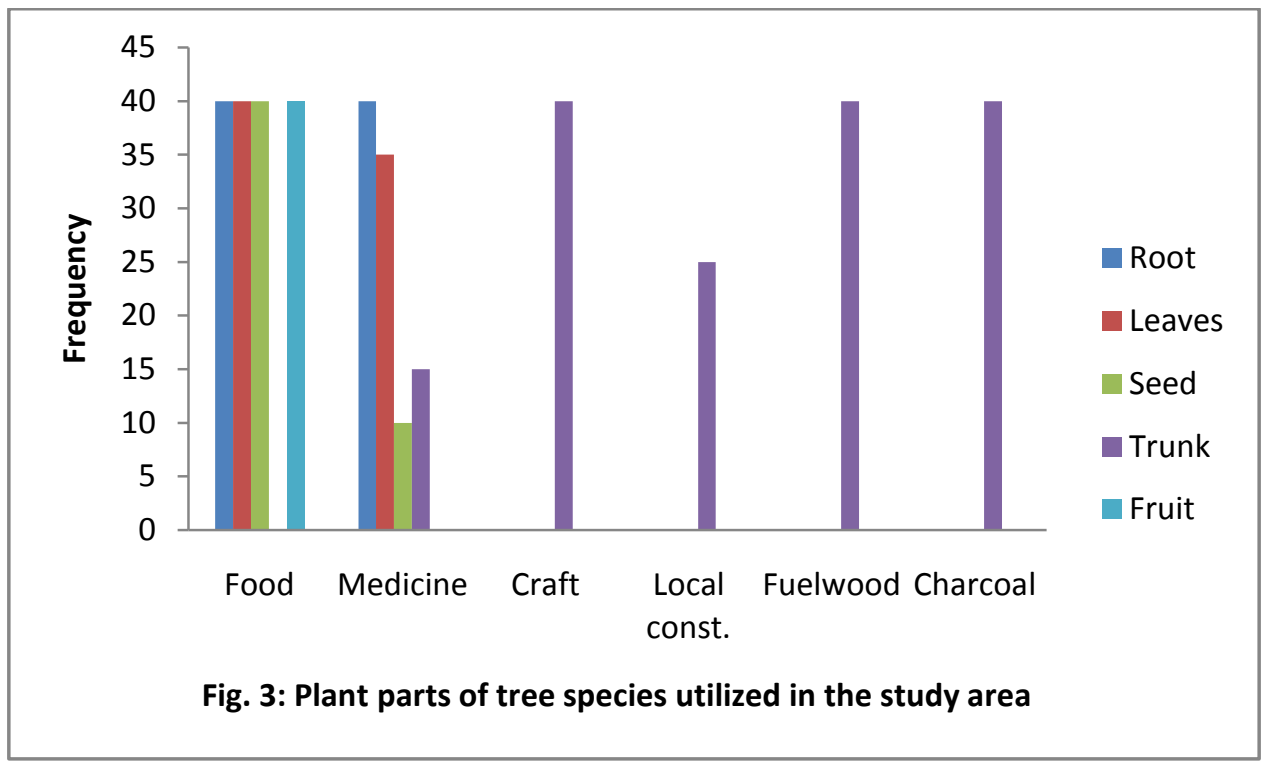

\section{Conclusion}

A total of 38 plant species from 17 families were recorded with combretaceae having the highest number of species. Plants with multiple uses had high importance value index with the highest number of citations. Daniellia oliveri, Parkia biglobosa, Ficus sur and Mitrygyna inermis were more diverse with relative frequencies of 5.95 each and among the most abundant species with relative densities of 8.24, 8.79, 8.24 and 6.59 respectfully. Plants in the area were utilized for food, medicinal purposes, crafts making, local construction and fuelwood with most uses leading to the cutting of the trees. Majority of respondents agreed that they do not plant these tree species, a situation which presents a bleak future for utilization of the tree species for different purposes in the study area. It is therefore recommended that planting of tree species especially those preferred by community members be encouraged among members of the community and other stakeholders to reduce the current rate of loss of the species and provide for future demand. Creation of awareness on the impacts of deforestation and the need to conserve wild tree resources may reduce the current rate of exploitation of preferred tree species in the community.

\section{References}

[1]. Adams, J.H., Mahmud, A.M and Muslim, N.E (2007). Cluster analysis on floristic and forest structure of hilly lowland forest in Lak Kawi, Sabah of Malaysia. Int. J. Bot.4:351-358

[2]. Agishi, E.C. Tiv, Idoma, Etulo, Igede,Akwaya,Hausa, English and Scientific names of plants, $2^{\text {nd }}$ Edition, Agitab publishers Ltd Makurdi.2010.

[3]. Arbonnier, M (2004). Trees, shrubs and lianas of West African dry zones, $2^{\text {nd }}$ Edition.CIRAD,MARGRAF PUBLISHERS GMBH MNHN,Germany.

[4]. Atakpama. W, F. Foléga, M. Dourma, Y. A. Woégan, B. Diwediga, K. Wala, K. Batawila and Akpagana, K (2014). Woody Species Diversity, Structure and Distribution of Sterculia setigera Del. in Togo, West Africa. Annual Research \& Review in Biology,4(24): 4511-4528

[5]. Balemie, K and Kebebew, F(2006). Ethnobotanical study of wild edible plants in Derashe and Kucha Districts, South Ethiopia. Journal of Ethnobiology and Ethnomedicine.

[6]. Berkes, F. (2008). Sacred ecology (2 ed.). New York and London: Routledge.

[7]. Bond and Midglay (2001).

[8]. Brearly, F. Q, Prajadinata, S., Kidd, P.S., Procto, J and Suriantata, J (2004). Structure and floristics of an old secondary rainforest in Central Kalimantan, Indonesia: a comparison with adjacent primary forests. Forest ecology and management 195: 385-397.

[9]. Buba, T. (2015). Impact of different types of land use on pattern of herbaceous plant community in the Nigerian Northern guinea savanna. Journal of Agriculture and Ecology Research International 4(4): 151-165

[10]. Bussmann RW, Gilbreath GG (2006), Solio J, Lutura M, Lutuluo R, Kunguru K, Wood N, Mathenge SG: Plant use of the Maasai of Sekenani Valley, Maasai Mara, Kenya. Journal of Ethnobiology and Ethnomedicine. 22.

[11]. Campbell BM(1987). The use of wild fruits in Zimbabwe. Economic Botany. 41:375-385.

[12]. Carney, J.R., Krenishky, J.M., Williamson, R.T., Luo, J., Carlson, T.J., Hsu, V.L. and Moswa, J.L. (1999). Maprouneacin, a new daphnane diterpenoid with potent antihyperglycemic activity from Maprounea africana. Journal of Natural products 62: 345-347

[13]. Chidumayo, E, D. Okali, G. Kowero and Larwanou, M (2001). Climate change and African forest and wildlife resources. African Forest Forum, Nairobi, KENYA

[14]. Chin YW (2006). Balunas MJ, Chai HB, Kinghorn AD. Drug discovery from natural sources. AAPS J. 8:239-53.

[15]. Cragg G.M and Newman D.J(2013). Natural products: a continuing source of novel drug leads. Biochim Biophys Acta. 1830(6):3670-95. 
[16]. Fowler M.W (2006). Plants, medicines and man. J. Sci. Food Agric. 2; 86:1797-1804.

[17]. Fraterrigo JM, Turner MG, Pearson SM (2006). Previous land use alters plant allocation and growth in forest herbs. Journal of Ecology. 94(3):548-557. DOI: 10.1111/j.1365-2745.2006.01081.x

[18]. Friedman J, Bolotin D, Rios M, Mendosa P, Cohen Y, Balick M.J (1993). A novel method for identification and domestication of indigenous useful plants in Amazonian Ecuador. In New Crops. Edited by: Janick J, Simon JE. Wiley, New York; 167-174

[19]. Grivetti LE, Ogle BM(2000). Value of traditional foods in meeting macro-and micronutrient needs: the wild plant connection. Nutrition Research Reviews. 13:31-46.

[20]. Hanke, W, Böhner J, Dreber N, Jürgens N, Schmiedel U, Wesuls D, Dengler, J(2014). The impact of livestock grazing on plant diversity: An analysis across dryland ecosystems and scales in southern Africa. Ecological Applications; 24:1188-1203.

[21]. Hooper, D.U, Chapin, F.S, Ewel, J.J. Hector, A,Ichausti, P, Lavorel, S, Lawton, J.H, Lodge, D. M, Loreau, M, Naeem, S, Schmid, B, Setala, H, Symstad, A. J,Vandermeer, J and Wardle, D.A (2005). Effects of biodiversity on ecosystem functioning: A consensus of current knowledge, Ecological monographs 75(1):3-35

[22]. Hui, G, Yu, B. G, Xing, D.H (2014). Impacts of grazing and mowing on reproductive behaviors of Stipa grandis and Stipa krylovii in a semiarid area. Journal of Arid Land. 6(1):97-104. DOI: 10.1007/s40333-013-0196-5

[23]. Iwara, A.I, Offiong, R.A, Njar, G.N and Ogundele, F.O (2012). The effects of land use change on the structure and floristic patterns of vegetation in Ugep, Nigeria. Journal of Environmental studies 2(1):101-113.

[24]. Keay, R. W. J.(1989). Trees of Nigeria. Clarendon Press, Oxford Walnut Street, Oxford OX2.

[25]. KIT(2003). Cultivating a Healthy Enterprise. In Bulletin 350 Royal Tropical Institute, Amsterdam, The Netherlands.

[26]. Kukshal S, Nautiyal BP, Anthwal A, Sharma, A Bhatt A.B (2009). Phytosociological investigation and life form pattern of grazing lands under pine canopy in temperate zone, Northwest Himalaya, India. Research Journal of Botany. 4(2):55-69. DOI: 10.3923/rjb.2009.55.69

[27]. Latzel V. (2008). Plant traits and regeneration of urban plant communities after disturbance: does the bud bank play any role? Applied Vegetation Science. 11(3):387-394. DOI: 10.3170/2008-7-18487

[28]. Ladio, A. H., \& M. Lozada (2004). Patterns of use and knowledge of wild edible plants in distinct ecological environments: a case study of a Mapuche community from northwestern Patagonia, Biodiversity Conservation 13, pp. 1153-1173.

[29]. Lepage,L.,Berestovoy, P.,Fluet, M.J.and Rochette, A. (2007). Working Group III-Human vulnerability and adaptation to climate variability in the sahel: communities, institutions and local dynamics. In Report on Canadian Contrbutions to the CIDA-CILSS Project(\#A030978-002). 154pp

[30]. Maigi, J.K and Marsh, S. E.(2006). Composition, structure and regeneration patterns in a gallery forest along the Tana river near Bura, Kenya.Forest Ecology Management 236:211-228

[31]. Martin, C.J (1999). E thnobotany: Plants and people conservation manual. London. Pp 1-67.

[32]. Medley KE, Kalibo HW(2007). Ethnobotanical survey of 'wild' woody plant resources at mount kasigau, Kenya. Journal of East African Natural History, 96(2):149-186

[33]. Mendoza-González G, Martínez ML, Rojas-Soto OR, Vázquez G, Gallego-Fernández J.B (2013). Ecological niche modeling of coastal dune plants and future potential distribution in response to climate change and sea level rise. In: Atakpama et al., 2014

[34]. Munn,T. (2002). Indigenous Knowledge, Peoples and Sustainable Practice, Encyclopedia of Global Environmental Change, Vol. 5. John Wiley \& Sons, Ltd, Chichester.

[35]. Olapade, O.E and Bakare, O. A (1992). Medicinal plants in Ibadan under threats of erosion; Our forest, Environment and Heritage; Challenges for our people. Akinsanmi, S A.(ed). Proceedings of $22^{\text {nd }}$ Annual conference of Forestry Association of Nigeria. 5558pp

[36]. Oriola, E.O (2009). Forestry for Sustainable Development in Nigeria. International Journal of African Studies. Issue 1, pp.11-16

[37]. Pei, S.J., (2001). Ethnobotanical approaches of traditional medicine studies: some experiences from Asia. Pharmaceutical Biology 39: 74-79. Priutte et al., (2004).

[38]. Randimbivololona $F(1996)$. Research, valorization and exploitation of biological resources for medicinal purposes in the Malagasy Republic (Madagascar). J Ethnopharmacol. 51:195-200.

[39]. Rim-Rukeh, A, G. Irerhievwie and I. E. Agbozu (2013).Traditional beliefs and conservation of natural resources: Evidences from selected communities in Delta State, Nigeria. International Journal of Biodiversity and Conservation. Vol 5(7):426-432

[40]. Saberwal, V, M Rangarajan and A Kothari (2001). People, Parks and Wildlife, Towards Coexistence (London: Sangam Books).

[41]. Shomkegh, S. A.,Mbakwe, R and Udeagha A. U (2016). Uses and Relative Abundance of Non-timber Forest Plants in Farmlands of Selected Tiv Communities in Benue State, Nigeria. Journal of Agriculture and Ecology Research International. In press

[42]. Sanderson, M.A, Skinner, R.H, Barker, D.J, Edwards, G.R, Tracy, B.F and Wedin, D.A (2004). Plant species diversity management of temperate forage and grazing land ecosystems. http://www.crop.scijournals.org/cgi/content/abstract/44/41132?

[43]. Shiva M.P (1996). Inventory of Forestry Resources for Sustainable Management and Biodiversity Conservation. New Delhi: Indus Publishing Company.

[44]. Signorini, M. A, Piredda, M. and Bruschi, P. (2009). Plants and traditional knowledge: An ethnobotanical investigation on Monte Ortobene. Journal of Ethnobiology and Ethnomedicine, Vol 5.

[45]. Turyahabwe, N and Tweheyo, M (2010). Does forest tenure influence forest vegetation characteristics? A comparative analysis of private, local and central government forest reserves in Central Uganda. The International Forestry Review 4:320-338.

[46]. Usher PJ (2000).Traditional ecological knowledge in environmental assessment and management. Arctic, 53(2):183-193.

[47]. Verburg, P.H, Schot, P., M, Dijst and A. Veldkamp (2004). Land use change modeling: Current practice and research priorities. Goe Journal 61:309-324.

[48]. Wala K, Woegan AY, Borozi W, Dourma M, Atato A, Batawila K, (2012). Assessment of vegetation structure and human impacts in the protected area of Alédjo (Togo). African J. Ecol.; 50:355-366.

[49]. Wangchuk, P(2004). Bioactive alkaloids from medicinal plants of Bhutan. M.Sc. thesis. Australia: Department of Chemistry, University of Wollongong.

[50]. Zent, S. (1999). The quandary of conserving ethnoecological knowledge. A Piaroa example. In: Ethnoecology. The University of Georgia. 